\title{
Regional Intraosseous Administration of Prophylactic Antibiotics is More Effective Than Systemic Administration in a Mouse Model of TKA
}

\author{
Simon W. Young FRACS, Tim Roberts MBChB, Sarah Johnson BSc, \\ James P. Dalton PhD, Brendan Coleman FRACS, Siouxsie Wiles PhD
}

Received: 10 February 2015/ Accepted: 14 July 2015/Published online: 30 July 2015

(C) The Author(s) 2015. This article is published with open access at Springerlink.com

\begin{abstract}
Background In human TKA studies, intraosseous regional administration (IORA) of prophylactic antibiotics achieves local tissue antibiotic concentrations 10 times greater than systemic administration. However, it is unclear if such high concentrations provide more effective prophylaxis.

Questions/purposes We asked: (1) What prophylaxis dosage and route (intravenous [IV] versus IORA of prophylactic antibiotics) produce less in vivo bacterial burden compared with no-antibiotic controls? (2) Compared with controls, what prophylaxis dosage and route yield fewer
\end{abstract}

The institution of one or more of the authors (SW) has received a grant-in-aid from the New Zealand Orthopaedic Association in relationship to this work. One of the authors (SW) was supported by a Sir Charles Hercus Fellowship from the Health Research Council of New Zealand (09/099).

All ICMJE Conflict of Interest Forms for authors and Clinical Orthopaedics and Related Research ${ }^{\mathbb{R}}$ editors and board members are on file with the publication and can be viewed on request.

Clinical Orthopaedics and Related Research ${ }^{\mathbb{R}}$ neither advocates nor endorses the use of any treatment, drug, or device. Readers are encouraged to always seek additional information, including FDAapproval status, of any drug or device prior to clinical use. Each author certifies that his or her institution approved the animal protocol for this investigation and that all investigations were conducted in conformity with ethical principles of research.

S. W. Young

Department of Surgery, University of Auckland, Auckland, New Zealand

S. W. Young ( $₫)$, T. Roberts, B. Coleman

Department of Orthopaedic Surgery, North Shore Hospital, 124 Shakespeare Road, Takapuna, Private Bag 93-503,

Auckland 0740, New Zealand

e-mail: simonwyoung@gmail.com colony-forming units (CFUs) in euthanized animals in a model of TKA? (3) Is prophylactic IORA of antibiotics more effective than same-dose IV antibiotic administration in reducing CFUs?

Methods Mice (six to nine per group) were block randomized to one of six prophylaxis regimens: control, systemic cefazolin $\left(\mathrm{C} 100_{\mathrm{IV}}\right)$, IORA of cefazolin $\left(\mathrm{C}_{100_{\text {IORA }}}\right)$, systemic vancomycin $\left(\mathrm{V} 110_{\mathrm{IV}}\right)$, low-dose systemic vancomycin (V25 IV), and low-dose IORA of vancomycin (V25 IORA). Surgery involved placement of an intraarticular knee prosthesis, followed by an inoculum of bioluminescent Staphylococcus aureus strain Xen36. Biophotonic imaging assessed in vivo bacterial loads, and after 4 days bacterial load was quantified using culture-based techniques. Comparisons were made for each prophylactic regimen to controls and between same-dose IV and IORA of prophylactic antibiotic regimens.

Results Mice treated with systemic high-dose vancomycin, IORA of vancomycin, or IORA of cefazolin had lower in vivo Staphylococcus aureus burdens (median area under curve, Control: $5.0 \times 10^{6}$; V110 IV: $1.5 \times 10^{6}$, difference of medians $3.5 \times 10^{6}, \mathrm{p}=0.003 ; \mathrm{V} 25_{\mathrm{IV}}$ : $1.94 \times 10^{6}$, difference $3.07 \times 10^{6}, \mathrm{p}=0.49 ;$ V25 IORA $1.51 \times 10^{6}$, difference $3.5 \times 10^{6}, \mathrm{p}=0.0011 ; \mathrm{C} 100_{\mathrm{IORA}}$ : $1.55 \times 10^{6}$, difference $3.46 \times 10^{6}, \mathrm{p}=0.0016 ; \mathrm{C} 100_{\mathrm{IV}}$ : $2.35 \times 10^{6}$, difference $2.66 \times 10^{6}, \mathrm{p}=0.23$.) Similar

S. Johnson, J. P. Dalton, S. Wiles

Bioluminescent Superbugs Laboratory, Faculty of Medical \& Health Sciences, University of Auckland, Auckland,

New Zealand

J. P. Dalton, S. Wiles

Maurice Wilkins Centre for Molecular Biodiscovery, Auckland, New Zealand 
findings were seen with culture-based techniques on recovered implants. IORA of prophylactic antibiotics was more effective than same-dose IV administration in reducing bacterial load on recovered implants (median CFUs $<7.0 \times 10^{0}$ vs $\left.2.83 \times 10^{2}, \mathrm{p}=0.0183\right)$.

Conclusions IORA of prophylactic cefazolin and vancomycin was more effective than the same dose of antibiotic given systemically. The effectiveness of vancomycin in particular was enhanced by IORA of prophylactic antibiotics despite using a lower dose.

Clinical relevance Our study supports previous studies of IORA of prophylactic antibiotics in humans and suggests this novel form of administration has the potential to enhance the effectiveness of prophylaxis in TKA. Because of concerns regarding antibiotic stewardship, IORA of prophylactic vancomycin may be more appropriately restricted to patients having TKA who are at greater risk of infection, and clinical trials are in progress.

\section{Introduction}

Prophylactic antibiotics aim to provide protection against the bacteria most likely to cause contamination during surgery $[5,57]$. The two most common bacteria causing contamination and subsequent deep infection in TKAs are Staphylococcus aureus and coagulase-negative staphylococci [14, 26, 37]. In the 1960s and 1970s when preoperative prophylactic antibiotics were introduced, as much as $98 \%$ of hospital isolates of coagulase-negative staphylococci and $97 \%$ of $S$ aureus were sensitive to cephalosporins $[18,27,33,42]$, and cephalosporins subsequently became the commonly recommended agent for prophylaxis in arthroplasty [7, 11, 23, 25]. Currently however, as much as $90 \%$ of hospital coagulase-negative staphylococci isolates are resistant to cephalosporins [14, $26,37,50,55]$, and $30 \%$ to $56 \%$ of $S$ aureus cultured from infected joint arthroplasties are methicillin-resistant (MRSA) [30, 31, 34, 39]. Vancomycin has been suggested as an alternative prophylactic agent, as currently it remains effective against MRSA and coagulase-negative staphylococci resistant to cefazolin [4, 49]. However injudicious use of vancomycin may risk further resistance, and in clinical studies it is a less-effective prophylactic agent than cefazolin against methicillin-sensitive $S$ aureus strains (MSSA) [4, 19]. This may be because adequate vancomycin tissue levels are not achieved with typical systemic doses [22, 42], particularly when timing of prophylactic administration is suboptimal [4, 17].

Higher tissue levels of antibiotic can be achieved with alternative methods of administration. Intraosseous regional administration (IORA) of prophylactic antibiotics is a novel form of administration that involves intraosseous injection after tourniquet inflation but before skin incision. In a randomized trial of patients who had TKAs comparing $1 \mathrm{~g}$ cefazolin given by IORA or systemic routes, IORA achieved 10 times greater antibiotic tissue concentrations [57]. IORA also achieves high tissue concentrations when lower doses of prophylactic antibiotic are used [56], an advantage for agents such as vancomycin where systemic toxicity including red man syndrome is a concern [9]. However it is unclear if these high tissue concentrations seen in clinical studies of IORA using either vancomycin or cefazolin provide more effective prophylaxis against infection.

The aim of our study was to compare the effectiveness of prophylactic IORA of antibiotics with systemic administration using an in vivo murine model of TKA [38]. Specifically, we asked: (1) What antibiotic administration dosage and route (intravenous [IV] versus IORA) produce less in vivo bacterial burden compared with no-antibiotic controls? (2) Compared with controls, what prophylactic antibiotic administration dosage and route yield fewer colony-forming units (CFUs) in euthanized animals in a model of TKA? (3) Is prophylactic IORA more effective than same-dose IV antibiotic administration in reducing CFUs?

\section{Materials and Methods}

\section{Bioluminescent $S$ aureus}

Bioluminescent MSSA Xen36 [6] (Perkin Elmer, Waltham, MA, USA) was used in all experiments. Xen36 is a derivative of clinical bacteremia isolate ATCC 49525 (Wright) with a modified lux operon from Photorhabdus luminescens stably integrated in a native plasmid [6].

Bacteria were grown overnight in Tryptic soy broth (Fort Richard Laboratories Ltd, Auckland, New Zealand) at $37{ }^{\circ} \mathrm{C}$ with shaking at $200 \mathrm{rpm}$, then reinoculated in fresh media at 1:5 and incubated for an additional 90 minutes. Bacteria then were checked for light expression, washed three times in phosphate-buffered saline (PBS), and resuspended in PBS to obtain approximately $5 \times 10^{9} \mathrm{CFU} /$ $\mathrm{mL}$. The concentration of bacteria in solution was verified retrospectively by plating and culture.

\section{Animals}

Female CD1 mice were obtained from the specific pathogen-free breeding facility at the University of Auckland. The mice were 7 to 9 weeks old on arrival and were given 
food and water ad libitum. Animals were housed and cared for in accordance with the New Zealand Animal Welfare Act [36] and institutional guidelines provided by the University of Auckland Animal Ethics Committee, which reviewed and approved these experiments under application R1134. As single housing of animals is discouraged, all experiments were performed using female mice, as they are less aggressive than males, and so less likely to injure themselves or each other when housed together. Conditions and diet were identical for all animals. To minimize the number of animals required, while accounting for any host, bacterial, or surgical variation, one experiment was performed using a block design (Fig. 1). Surgery was performed on six separate occasions using a different cohort of mice and a fresh preparation of bacteria. At each surgery six to eight animals were randomized to one of the six experimental groups, to give group sizes of six to eight animals.
Antibiotic Prophylaxis

Mice were randomized into six experimental groups: (1) no antibiotic prophylaxis $(\mathrm{n}=7)$; (2) systemic vancomycin $\left(110 \mathrm{mg} / \mathrm{kg}, \mathrm{V} 110_{\mathrm{IV}}, \mathrm{n}=6\right)$; (3) systemic vancomycin $(25$ $\left.\mathrm{mg} / \mathrm{kg}, \mathrm{V} 25_{\mathrm{IV}}, \mathrm{n}=6\right)$; (4) intraosseous vancomycin $(25 \mathrm{mg} /$ $\left.\mathrm{kg}, \mathrm{V} 25_{\text {IORA }}, \mathrm{n}=7\right)$; (5) intraosseous cefazolin $(100 \mathrm{mg} / \mathrm{kg}$, $\left.\mathrm{C} 100_{\text {IORA }}, \mathrm{n}=9\right)$; and (6) systemic cefazolin $(100 \mathrm{mg} / \mathrm{kg}$, $\left.\mathrm{C} 100_{\mathrm{IV}}, \mathrm{n}=7\right)$. These experimental groups represent vancomycin IV at either a high therapeutic dose $(110 \mathrm{mg} / \mathrm{kg})$ or a suboptimal dose $(25 \mathrm{mg} / \mathrm{kg})$ or intraosseously at a low dose $(25 \mathrm{mg} / \mathrm{kg})$. We administered cefazolin at a standard therapeutic dose either IV or intraosseously. These reflect the dosages and routes of administration used in two previous human studies of IORA $[56,57]$. One mouse from the IORA cefazolin $(100 \mathrm{mg} / \mathrm{kg})$ group and one from the systemic vancomycin $(25 \mathrm{mg} / \mathrm{kg})$ group were euthanized for losing more than $20 \%$ of baseline body weight per

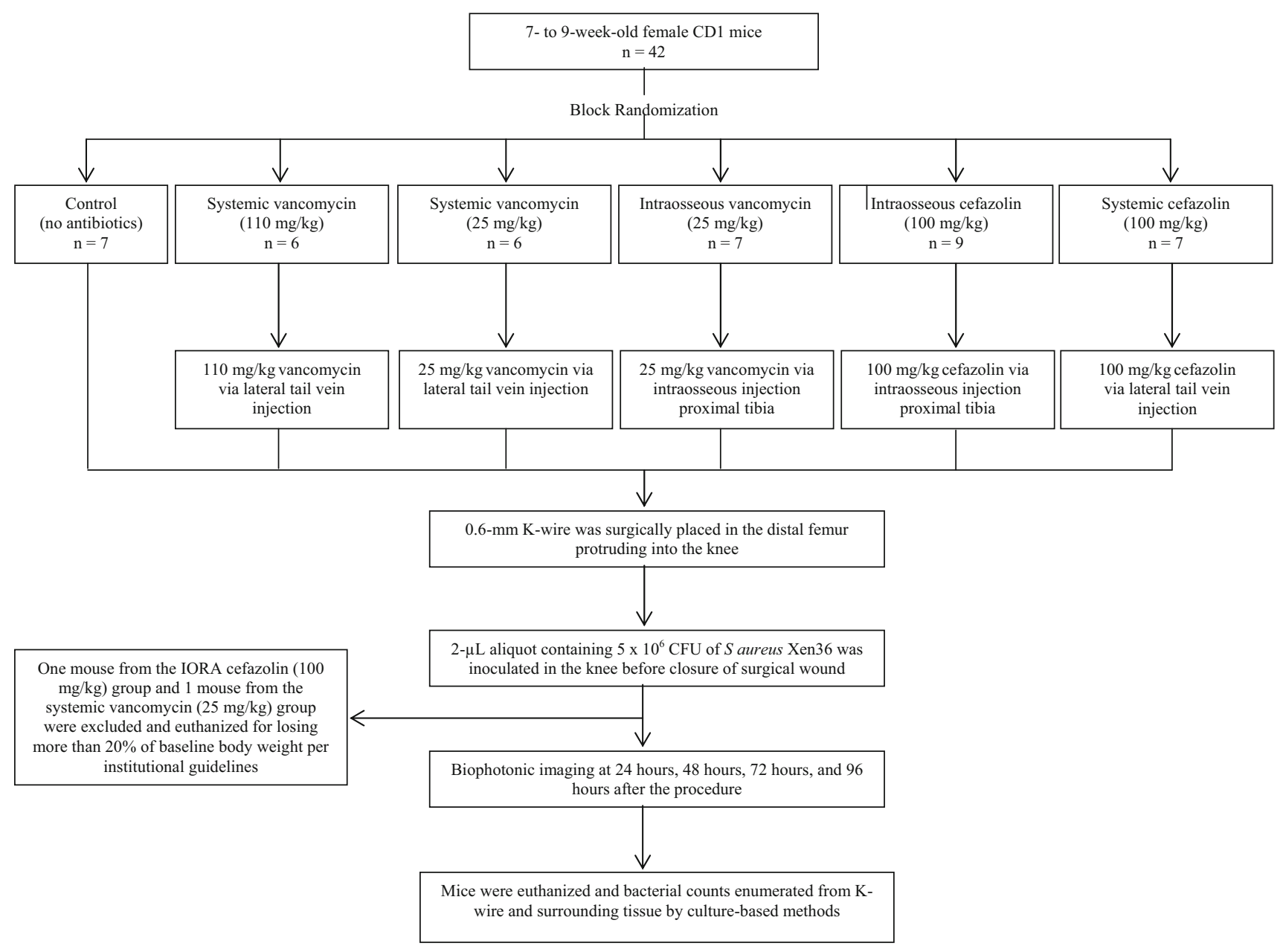

Fig. 1 A schematic of the experimental design we used in this study is shown. 
institutional guidelines and were excluded from the analysis (Fig. 1).

Antibiotics, when used, were administered either systemically via an IV route or regionally (below a tourniquet) via an intraosseous route. Systemic antibiotics were introduced by injection into the lateral tail vein 30 minutes before surgery. Regional intraosseous antibiotics, however, were administered by direct injection into the proximal tibia after tourniquet inflation to the extremity and immediately before surgery. Antibiotics were given by intraosseous injection into the tibia using a 26-gauge needle as previously described [24, 29, 47]. The $110 \mathrm{mg} / \mathrm{kg}$ dose of vancomycin is an effective dose in mice, approximating the area under the curve (AUC) of $400 \mathrm{mg} . \mathrm{hour} / \mathrm{L}$ for a typical human dose of vancomycin ( $1 \mathrm{~g}$ every 12 hours) [20, 38]. Using the body surface normalization method [44], this represents a human dose of approximately 10 to $15 \mathrm{mg} / \mathrm{kg}$. We used an IORA dose of vancomycin that was approximately $25 \%$ of this, as reported in a human study, where a lower dose was used to protect against systemic effects such as red man syndrome [56]. Because cefazolin has minimal systemic toxicity, we used the same dose for the systemic and IORA routes as in a previous IORA study of humans [57]. The cefazolin dose of $100 \mathrm{mg} / \mathrm{kg}$ in mice gives serum concentrations similar to a 1 - to $2-\mathrm{g}$ prophylactic dose in humans [8, 28, 54].

\section{Surgical Procedure}

Mice were weighed preoperatively and inhalational isoflurane $(3.0 \%)$ was administered for anesthesia. In the absence of a toe pinch reflex, the right leg was depilated using clippers and an above-knee tourniquet was applied. The surgical site was prepared using an iodine-povidone swab followed by an alcohol swab and a final iodinepovidone wash.

The knee was accessed using a medial parapatellar approach and the intercondylar region of the distal femur identified. The femoral medullary canal was reamed manually with sequentially larger-gauge needles for the stainless steel implant, starting with a 26-gauge needle. A sterile $0.6-\mathrm{mm} \mathrm{K}$-wire then was inserted in a retrograde fashion through the intercondylar region into the intramedullary cavity of the distal femur. The K-wire was cut with approximately $1 \mathrm{~mm}$ of wire protruding in the joint cavity. Before closing, a $2-\mu \mathrm{L}$ aliquot containing approximately $5 \times 10^{6}$ CFU of $S$ aureus Xen36 was pipetted into the joint. The patella complex then was reduced and the incision closed with 6-0 Monocryl ${ }^{\mathrm{TM}}$ sutures (Ethicon, Somerville, NJ, USA). The total tourniquet time for each mouse was 30 minutes. Postoperatively, the mice received acetaminophen (paracetamol) $(6 \mathrm{mg} / \mathrm{mL})$ in the drinking water and carprofen $(5 \mathrm{mg} / \mathrm{kg})$ subcutaneously once daily.

\section{Biophotonic Imaging}

Biophotonic imaging was used to noninvasively measure the bioluminescent signal emitted by $S$ aureus Xen36 from anesthetized mice to provide information regarding the localization of the bacterium (given as photons per second per square centimeter per steradian [photons second $/ \mathrm{cm}^{2} /$ sr]) (Fig. 2). We also quantified the bacterial burden in vivo from the biophotonic signal of selected regions of interest (given as photons/second) using Living Image software (Perkin Elmer) (Fig. 3). Measurements were obtained daily to present as values for the AUC for each animal (Fig. 4).

Assessment of bioluminescence (photons $/$ second $/ \mathrm{cm}^{2} /$ sr) from living animals was measured after gaseous anesthesia with isoflurane using the IVIS ${ }^{\circledR}$ Kinetic camera system (Perkin Elmer). A photograph (reference image) was taken under low illumination before quantification of photons emitted from Xen36 at a binning of four over 5 minutes using the Living Image software. For anatomic localization, a pseudocolor image representing light intensity (blue, least intense to red, most intense) was generated using the Living Image software and superimposed over the gray-scale reference image. Bioluminescence in specific regions of individual mice also was quantified using the region of interest tool in the Living Image software program (given as photons per second).

\section{Quantification of Bacteria in the Knee and Implant}

Mice were euthanized by cervical dislocation under anesthesia. The hindlimb was surface-sterilized with $70 \%$ ethanol and the skin removed. The knee (including approximately $5 \mathrm{~mm}$ of the proximal end of tibia and distal end of femur) and surrounding tissue were excised. The Kwire was extracted from the femur and placed in a $1.5-\mathrm{mL}$ microtube containing $0.5 \mathrm{~mL}$ PBS. The excised knee was placed in a $2-\mathrm{mL}$ sample tube containing ceramic beads and $1 \mathrm{~mL}$ PBS and homogenized $(3 \times 10$ seconds at 3.55 $\mathrm{m} / \mathrm{second}$ ) using a tissue disruptor (OMNI International, Kennesaw, GA, USA). Serial dilutions were plated on Mannitol salt agar (Fort Richard Laboratories Ltd) and grown overnight at $37{ }^{\circ} \mathrm{C}$ for viable count enumeration. Plates subsequently were imaged with the IVIS ${ }^{\circledR}$ Kinetic camera system to confirm recovery of bioluminescent $S$ aureus Xen36. 


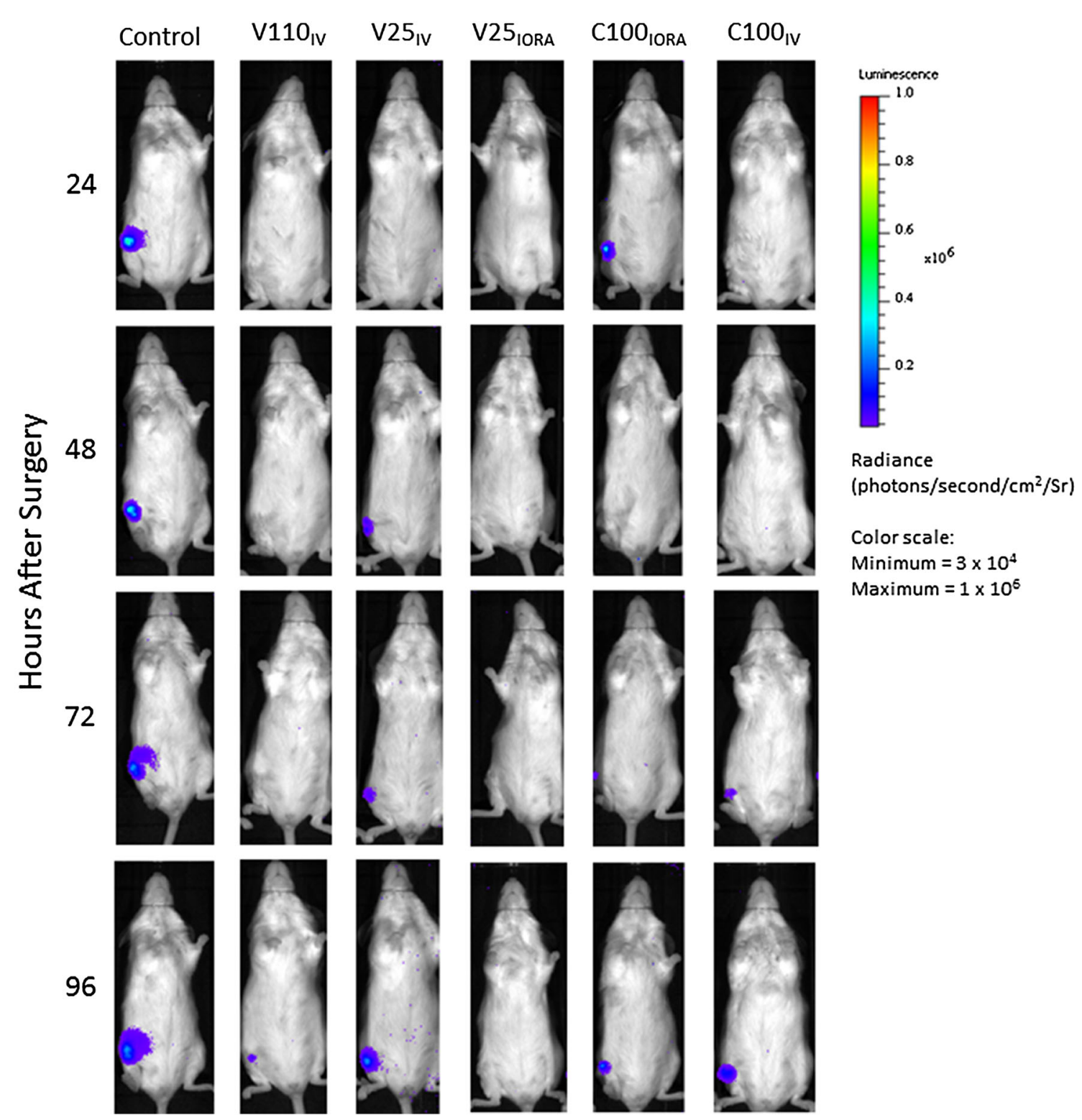

Fig. 2 Bioluminescence from $S$ aureus Xen36 from anesthetized animals was assessed after surgery. The images show peak bioluminescence with variations in color representing light intensity at a given location. Red represents the most intense light emission, whereas blue corresponds to the weakest signal. The color bar indicates relative signal intensity (as photons $/ \mathrm{second} / \mathrm{cm}^{2} /$ steradian [Sr]). Mice were imaged at various times after surgery with an

\section{Statistics}

Data analysis was performed using the GraphPad Prism (V6) software package (GraphPad Software Inc, La Jolla, CA, USA). Briefly, in vivo bacterial burdens (measured as photons per second and calculated AUC values for each animal) were compared between controls and each treatment group using the Kruskal-Wallis test and Dunn's post hoc analysis. Ex vivo bacterial burdens from tissue samples integration time of 5 minutes. One representative animal is shown for each group. IV = intravenous; IORA $=$ intraosseous regional administration; V110 $\mathrm{IV}=$ systemic vancomycin, $110 \mathrm{mg} / \mathrm{kg} ; \mathrm{V} 25_{\mathrm{IV}}$ = systemic vancomycin, $25 \mathrm{mg} / \mathrm{kg} ; \mathrm{V} 25_{\text {IORA }}=\mathrm{IORA}$ vancomycin, 25 $\mathrm{mg} / \mathrm{kg} ; \mathrm{C} 100_{\mathrm{IORA}}=\mathrm{IORA}$ cefazolin, $100 \mathrm{mg} / \mathrm{kg} ; \mathrm{C} 100_{\mathrm{IV}}=$ systemic cefazolin, $100 \mathrm{mg} / \mathrm{kg}$.

and implanted K-wires (measured as CFUs for each animal) were compared between controls and each treatment group using the Kruskal-Wallis test and Dunn's post hoc analysis. Ex vivo bacterial burdens from tissue samples and implanted K-wires also were compared between same dose IV and IORA treatments using a two-tailed Mann Whitney test. The number of animals with culture-positive or negative K-wires was compared using Fisher's exact test comparing same dose IV versus IORA treatment. 


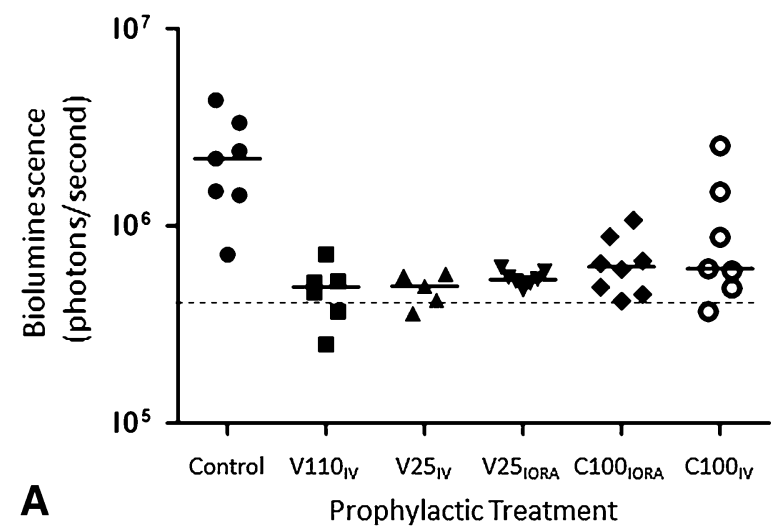

Fig. 3A-B Quantification of bioluminescence from $S$ aureus Xen36 from anesthetized animals after surgery is shown. The bioluminescent signals originating from individual animals at (A) 1 day and (B) 4 days after surgery were obtained using the region of interest tool in the Living Image software program (given as photons/second). The dotted line represents the level of background from uninfected animals. Median values per group are denoted by solid lines. Each

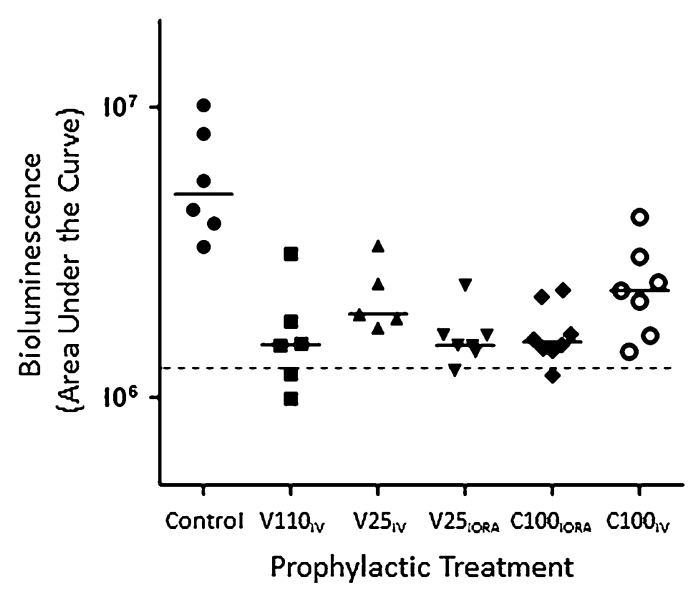

Fig. 4 Area under curve values (summation during entire test period) from bioluminescent signals obtained throughout the experiment are shown. The dotted line represents the level of background from uninfected animals. Median values per group are denoted by solid lines. Each symbol represents an individual animal. Data are pooled from six independent repeats with one to two animals per group per repeat. IV = intravenous; IORA = intraosseous regional administration; $\mathrm{V} 110_{\mathrm{IV}}=$ systemic vancomycin, $110 \mathrm{mg} / \mathrm{kg} ; \mathrm{V} 25_{\mathrm{IV}}=$ systemic vancomycin, $25 \mathrm{mg} / \mathrm{kg}$; V25 IORA $=$ IORA vancomycin, $25 \mathrm{mg} / \mathrm{kg}$; $\mathrm{C} 100_{\text {IORA }}=$ IORA cefazolin, $100 \mathrm{mg} / \mathrm{kg} ; \mathrm{C} 100_{\mathrm{IV}}=$ systemic cefazolin, $100 \mathrm{mg} / \mathrm{kg}$.

\section{Results}

Influence of Antibiotic Dosage and Route on Bacterial Burden (Biophotonic Imaging)

Biophotonic imaging showed lower levels of bioluminescent bacteria in all vancomycin-treated animals as early as 1 day after surgery (Table 1)(median bioluminescence,

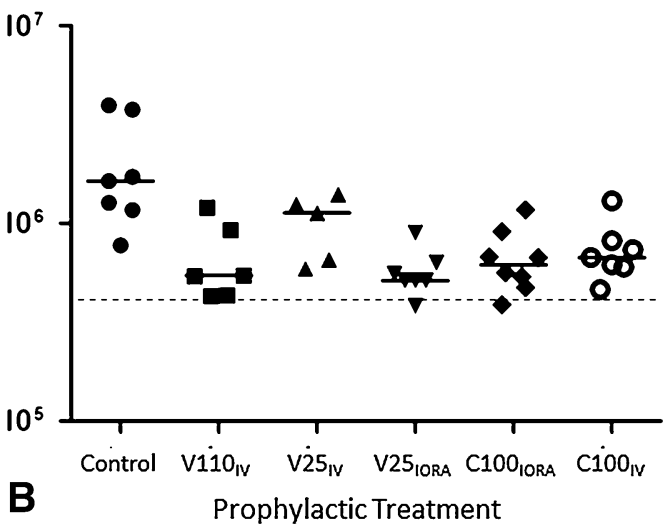

symbol represents an individual animal. Data are pooled from six independent repeats with one to two animals per group per repeat. IV = intravenous; IORA = intraosseous regional administration; $\mathrm{V} 110_{\mathrm{IV}}$ = systemic vancomycin, $110 \mathrm{mg} / \mathrm{kg} ; \mathrm{V} 25_{\mathrm{IV}}=$ systemic vancomycin,

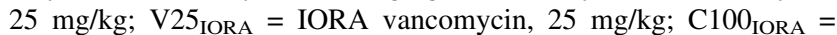
IORA cefazolin, $100 \mathrm{mg} / \mathrm{kg} ; \mathrm{C} 100_{\mathrm{IV}}=$ systemic cefazolin, $100 \mathrm{mg} / \mathrm{kg}$.

Control: $2.2 \times 10^{6}$ [range, $7.2 \times 10^{5}-4.3 \times 10^{6}$ ]; V110 IV: $4.9 \times 10^{5}$ [range, $2.5 \times 10^{5}-7.2 \times 10^{5}$ ], difference of median: $1.7 \times 10^{6}, \mathrm{p}=0.0016 ; \mathrm{V} 25_{\mathrm{IV}}: 4.9 \times 10^{5}[$ range, $3.6 \times 10^{5}-5.7 \times 10^{5}$ ], difference of medians: $1.7 \times 10^{6}, \mathrm{p}$ $=0.0028 ;$ V25 IORA $: 5.3 \times 10^{5}$ [range, $4.73 \times 10^{5}-$ $6.15 \times 10^{5}$ ], difference of medians: $1.7 \times 10^{6}, p=0.0148$ ) (Fig. 3A). With the numbers available, there was no difference in bioluminescence between untreated animals and those treated with cefazolin (median bioluminescence, Control: $2.2 \times 10^{6} \quad$ [range, $7.15 \times 10^{5}-4.34 \times 10^{6}$ ]; C100 IORA: $6.2 \times 10^{5}$ [range, $4.1 \times 10^{5}-1.1 \times 10^{6}$ ], p = $0.0606 ; \quad \mathrm{C} 100_{\mathrm{IV}}: \quad 6.1 \times 10^{5} \quad$ [range, $3.68 \times 10^{5}-$ $\left.2.55 \times 10^{6}\right], p=0.2335$ ) (Fig. $3 \mathrm{~A}$ ).

At 4 days after surgery, the bioluminescent signals from animals treated with a suboptimal concentration of vancomycin IV (V25 IV) returned to near control levels. However, the bioluminescent signals obtained from animals administered high-dose systemic IV vancomycin $\left(\mathrm{V} 110_{\mathrm{IV}}\right)$, low-dose regional intraosseous vancomycin (V25 IORA), and regional intraosseous cefazolin (C100 IORA), were lower than those from control animals at this time (median bioluminescence (Table 2): Control: $1.64 \times 10^{6} \quad$ [range, $7.76 \times 10^{5}-3.96 \times 10^{6}$ ]; V110 IV: $5.45 \times 10^{5}$ [range, $4.30 \times 10^{5}-1.20 \times 10^{6}$ ], difference of median: $1.10 \times 10^{6}, \mathrm{p}=0.013$; V25 $\mathrm{IV}: 1.13 \times 10^{6}$ [range, $\left.5.91 \times 10^{5}-1.40 \times 10^{6}\right]$, difference of median: $5.10 \times 10^{6}, \mathrm{p}>0.99 ; \mathrm{V} 25_{\text {IORA }}: 5.14 \times 10^{5}$ [range, $\left.3.83 \times 10^{5}-8.96 \times 10^{5}\right]$, difference of medians: $1.13 \times 10^{6}, \mathrm{p}=0.0012 ; \mathrm{C} 100_{\mathrm{IORA}}: 6.18 \times 10^{5}$ [range, $3.88 \times 10^{5}-1.17 \times 10^{6}$ ], difference of medians: $1.02 \times 10^{6}, \mathrm{p}=0.0140 ; \mathrm{C} 100_{\mathrm{IV}}: 6.72 \times 10^{5}$ [range, $4.63 \times 10^{5}-1.30 \times 10^{6}$ ], difference of medians: 
Table 1. Staphylococcus aureus bioluminescence Day 1 after surgery for antibiotic treatment compared with no treatment

\begin{tabular}{|c|c|c|c|}
\hline Treatment & Median (range)* & Difference of medians to control* & $\mathrm{p}$ value \\
\hline Control & $2.19 \times 10^{6}\left(7.15 \times 10^{5}-4.34 \times 10^{6}\right)$ & & \\
\hline V110 IV & $4.90 \times 10^{5}\left(2.51 \times 10^{5}-7.20 \times 10^{5}\right)$ & $1.70 \times 10^{6}$ & 0.0016 \\
\hline $\mathrm{V} 25_{\mathrm{IV}}$ & $4.94 \times 10^{5}\left(3.60 \times 10^{5}-5.70 \times 10^{5}\right)$ & $1.70 \times 10^{6}$ & 0.0028 \\
\hline V25 IORA & $5.34 \times 10^{5}\left(4.73 \times 10^{5}-6.15 \times 10^{5}\right)$ & $1.66 \times 10^{6}$ & 0.0148 \\
\hline C100 IORA & $6.21 \times 10^{5}\left(4.14 \times 10^{5}-1.07 \times 10^{6}\right)$ & $1.57 \times 10^{6}$ & 0.0606 \\
\hline $\mathrm{C} 100_{\mathrm{IV}}$ & $6.06 \times 10^{5}\left(3.68 \times 10^{5}-2.55 \times 10^{6}\right)$ & $1.58 \times 10^{6}$ & 0.2335 \\
\hline
\end{tabular}

* Photons/second; $\mathrm{C}=$ cefazolin; $\mathrm{V}$ = vancomycin; IV = intravenous; IORA = intraosseous regional administration.

Table 2. Staphylococcus aureus bioluminescence 4 days after surgery for antibiotic treatment compared with no treatment

\begin{tabular}{lllr}
\hline Treatment & Median $(\text { range })^{*}$ & Difference of medians to control* & $p$ value \\
\hline Control & $1.64 \times 10^{6}\left(7.76 \times 10^{5}-3.96 \times 10^{6}\right)$ & & \\
V110 & $5.45 \times 10^{5}\left(4.30 \times 10^{5}-1.20 \times 10^{6}\right)$ & $1.10 \times 10^{6}$ & $5.10 \times 10^{5}$ \\
V25 $_{\text {IV }}$ & $1.13 \times 10^{6}\left(5.91 \times 10^{5}-1.40 \times 10^{6}\right)$ & $1.13 \times 10^{6}$ & $>0126$ \\
V25 IORA & $5.14 \times 10^{5}\left(3.83 \times 10^{5}-8.96 \times 10^{5}\right)$ & $1.02 \times 10^{6}$ & 0.0012 \\
C100 IORA & $6.18 \times 10^{5}\left(3.88 \times 10^{5}-1.17 \times 10^{6}\right)$ & $9.68 \times 10^{5}$ & 0.0140 \\
C100 & $6.72 \times 10^{5}\left(4.63 \times 10^{5}-1.30 \times 10^{6}\right)$ & 0.1015 \\
\hline
\end{tabular}

* Photons/second; $\mathrm{C}=$ cefazolin; $\mathrm{V}$ = vancomycin; IV = intravenous; IORA = intraosseous regional administration.

Table 3. Staphylococcus aureus bioluminescence area under curve values during 4 days for antibiotic treatment compared with no treatment

\begin{tabular}{|c|c|c|c|}
\hline Treatment & Median (range) & Difference of medians to control & $\mathrm{p}$ value \\
\hline Control & $5.01 \times 10^{6}\left(3.30 \times 10^{6}-1.02 \times 10^{7}\right)$ & & \\
\hline $\mathrm{V} 110_{\mathrm{IV}}$ & $1.52 \times 10^{6}\left(9.93 \times 10^{5}-3.13 \times 10^{6}\right)$ & $3.49 \times 10^{6}$ & 0.0026 \\
\hline $\mathrm{V} 25_{\mathrm{IV}}$ & $1.94 \times 10^{6}\left(1.75 \times 10^{6}-3.35 \times 10^{6}\right)$ & $3.07 \times 10^{6}$ & 0.4934 \\
\hline V25 IORA & $1.51 \times 10^{6}\left(1.25 \times 10^{6}-2.43 \times 10^{6}\right)$ & $3.50 \times 10^{6}$ & 0.0011 \\
\hline C100 IORA & $1.55 \times 10^{6}\left(1.19 \times 10^{6}-2.35 \times 10^{6}\right)$ & $3.46 \times 10^{6}$ & 0.0016 \\
\hline $\mathrm{C} 100_{\mathrm{IV}}$ & $2.35 \times 10^{6}\left(1.44 \times 10^{6}-4.16 \times 10^{6}\right)$ & $2.66 \times 10^{6}$ & 0.2312 \\
\hline
\end{tabular}

$\mathrm{V}=$ vancomycin; $\mathrm{C}=$ cefazolin; $\mathrm{IV}=$ intravenous; IORA = intraosseous regional administration.

Table 4. Staphylococcus aureus recovered from implant 4 days after surgery* for effect of antibiotic treatment compared with no treatment

\begin{tabular}{lclr}
\hline Treatment & Median (range) & Difference of medians to control & $\mathrm{p}$ value \\
\hline Control & $1.03 \times 10^{4}\left(1.08 \times 10^{3}-5.75 \times 10^{5}\right)$ & & \\
V110 & $9.17 \times 10^{1}\left(<7.0 \times 10^{0}-2.00 \times 10^{3}\right)$ & $1.02 \times 10^{4}$ & 0.0313 \\
V25 $_{\text {IV }}$ & $4.96 \times 10^{2}\left(<7.0 \times 10^{0}-2.13 \times 10^{3}\right)$ & $9.80 \times 10^{3}$ & 0.0905 \\
V25 $_{\text {IORA }}$ & $<7.0 \times 10^{0}\left(<7.0 \times 10^{0}-4.08 \times 10^{3}\right)$ & $1.03 \times 10^{4}$ & 0.0013 \\
C100 & $8.85 \times 10^{0}\left(<7.0 \times 10^{0}-6.17 \times 10^{2}\right)$ & $1.03 \times 10^{4}$ & 0.0020 \\
C100 & $2.83 \times 10^{2}\left(1.67 \times 10^{1}-1.62 \times 10^{4}\right)$ & $1.00 \times 10^{4}$ & 0.8858
\end{tabular}

$\mathrm{CFU}$ = colony forming units; $\mathrm{V}=$ vancomycin; $\mathrm{C}=$ cefazolin; IV = intravenous; IORA = intraosseous regional administration.

$9.68 \times 10^{5}, \mathrm{p}=0.1015$ (Fig. 3B). Likewise, AUC values calculated for the bioluminescence signals from treated mice throughout the experiment were approximately $1 / 4$ the value of those calculated for the untreated controls (median bioluminescence (Table 3): Control: $5.01 \times 10^{6}$ [range, $3.30 \times 10^{6}-1.02 \times 10^{7}$ ]; V110 IV: $1.52 \times 10^{6} \quad$ [range, 
$\left.9.93 \times 10^{5}-3.13 \times 10^{6}\right]$, difference of median: $3.49 \times$ $10^{6}, \mathrm{p}=0.0026 ; \mathrm{V} 25_{\mathrm{IV}}: 1.94 \times 10^{6}$ [range, $1.75 \times 10^{6}-$ $3.35 \times 10^{6}$ ], difference of median: $3.07 \times 10^{6}, p=0.4934$; V25 IORA: $1.51 \times 10^{6}$ [range, $1.25 \times 10^{6}-2.43 \times 10^{6}$ ], difference of medians: $3.50 \times 10^{6}, \mathrm{p}=0.0011$; C100 IORA $1.55 \times 10^{6}$ [range, $1.19 \times 10^{6}-2.35 \times 10^{6}$ ], difference of medians: $3.46 \times 10^{6}, \mathrm{p}=0.0016 ; \mathrm{C} 100_{\mathrm{IV}}: 2.35 \times 10^{6}$ [range, $1.44 \times 10^{6}-4.16 \times 10^{6}$ ], difference of median: $2.66 \times 10^{6}, \mathrm{p}=0.2312$ ) (Fig. 4).

Influence of Antibiotic Dosage and Route on $S$ aureus Survival (CFU Counts)

Similar to data from biophotonic imaging, CFUs obtained from the implanted K-wire were lower in the high-dose systemic IV vancomycin, low-dose regional intraosseous vancomycin, and regional intraosseous cefazolin groups than controls (Table 4)(median CFUs, Control: $1.03 \times 10^{4}$ [range, $1.08 \times 10^{3}-5.75 \times 10^{5}$ ]; V110 $\mathrm{IV}: \quad 9.17 \times 10^{1}$ [range, $<7.0 \times 10^{0}-2.00 \times 10^{3}$ ], difference of median: $1.02 \times 10^{4}, \mathrm{p}=0.0313 ; \mathrm{V} 25_{\mathrm{IV}}: 4.96 \times 10^{2}$ [range, $<$ $7.0 \times 10^{0}-2.13 \times 10^{3}$ ], difference of median: $9.80 \times 10^{3}$, $\mathrm{p}=0.0905 ; \mathrm{V} 25_{\text {IORA }}$ : $<7.0 \times 10^{0}$ [range, $<7.0 \times 10^{0}-$ $4.08 \times 10^{3}$ ], difference of medians: $1.03 \times 10^{4}, \mathrm{p}=$ $0.0013 ; \mathrm{C}_{100}$ IORA $: 8.85 \times 10^{\circ}$ [range, $<7.0 \times 10^{\circ}-$ $6.17 \times 10^{2}$ ], difference of medians: $1.03 \times 10^{4}, \mathrm{p}=$ $0.0020 ; \quad \mathrm{C} 100_{\mathrm{IV}}: 2.83 \times 10^{2} \quad$ [range, $1.67 \times 10^{1}-$ $1.62 \times 10^{4}$ ], difference of median: $1.00 \times 10^{4}, \mathrm{p}=$ 0.8858) (Fig. 5).

Although bacteria were recovered from the tissues surrounding the implant site for all but one animal, mice treated with intraosseous vancomycin or cefazolin had lower numbers (Table 5): (median CFUs, Control:

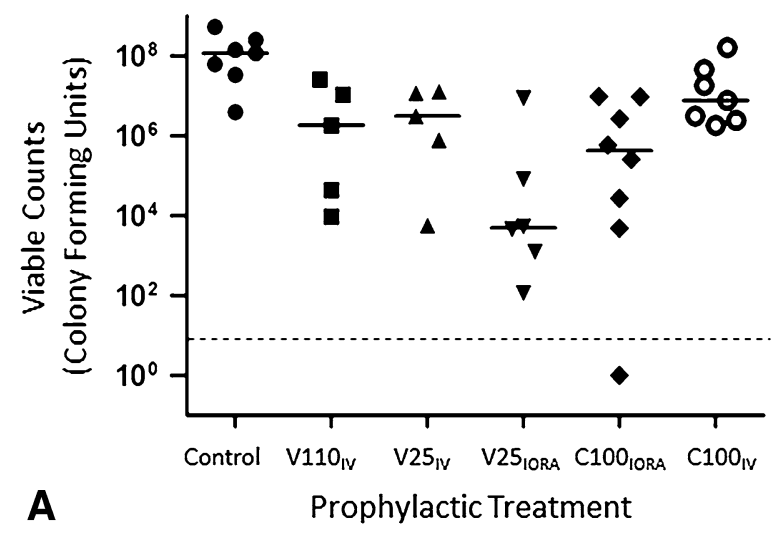

Fig. 5A-B Quantification of viable $S$ aureus Xen36 after surgery is shown. The mice were euthanized 96 hours after surgery for quantification of bacteria remaining in the (A) knee and surrounding tissue and (B) implanted K-wire. The dotted line represents the limits of detection. Median values per group are denoted by solid lines. Each symbol represents an individual animal. Data are pooled from six
$1.17 \times 10^{8} \quad$ [range, $3.94 \times 10^{6}-5.37 \times 10^{8}$ ]; V110 IV: $1.86 \times 10^{6}$ [range, $9.59 \times 10^{3}-2.60 \times 10^{7}$ ], difference of median: $1.15 \times 10^{8}, \mathrm{p}=0.1376 ; \mathrm{V} 25_{\mathrm{IV}}$ : $1.95 \times 10^{6}$ [range, $6.64 \times 10^{2}-1.27 \times 10^{7}$ ], difference of median: $1.15 \times 10^{8}, \mathrm{p}=0.0454 ;$ V25 IORA: $4.92 \times 10^{3}$ [range, $1.16 \times 10^{2}-8.69 \times 10^{6} \mathrm{]}$, difference of medians: $1.17 \times 10^{8}, \mathrm{p}=0.0005 ; \mathrm{C} 100_{\mathrm{IORA}}: 4.23 \times 10^{5}$ [range, $<$ $1.30 \times 10^{1}-9.69 \times 10^{6}$ ] difference of medians: $1.17 \times 10^{8}, \mathrm{p}=0.0049 ; \mathrm{C} 100_{\mathrm{IV}}: 7.67 \times 10^{6}$ [range, $1.82 \times 10^{6}-1.63 \times 10^{8}$ ], difference of median: $1.09 \times 10^{8}, \mathrm{p}=0.8699$ (Fig. 5).

IORA versus Same-dose IV Antibiotic Administration

Overall, intraosseous antibiotic administration was more effective at reducing the burden of contaminating bacteria in the tissue than the same dose of antibiotic administered IV (median CFUs, IV: $3.16 \times 10^{6}$ [range, $6.64 \times 10^{2}-$ $1.63 \times 10^{8}$ ]; IORA: $5.43 \times 10^{4}$ [range, $<1.30 \times 10^{1}-$ $9.69 \times 10^{6}$ ] difference of medians: $3.11 \times 10^{6}, \mathrm{p}=0.0163$ ) (Fig. 6A). Bacteria were recovered from the K-wires implanted in only five of 14 IORA-treated animals compared with 11 of 13 animals treated intravenously with the same dose of antibiotic (Fisher's exact $\mathrm{p}=0.0183$; median CFUs, IV: $2.83 \times 10^{2}$ [range, $<7.0 \times 10^{0}-1.62 \times 10^{4}$ ]; IORA: $<7.0 \times 10^{0}$ [range, $<7.0 \times 10^{0}-4.08 \times 10^{3}$ ] difference of medians: $2.76 \times 10^{2}, \mathrm{p}=0.0073$ ) (Fig. 6B).

\section{Discussion}

Prophylactic antibiotics reduce deep infection rates in arthroplasty [13, 23]. To be effective, prophylactic

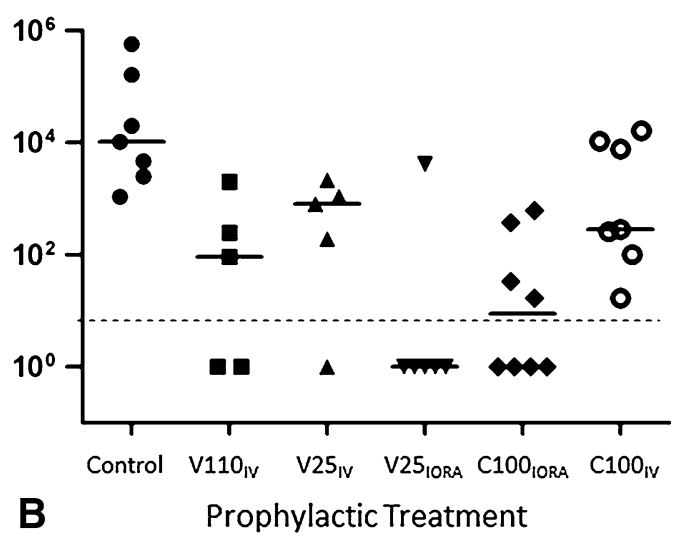

independent repeats with one to two animals per group per repeat. IV = intravenous; IORA = intraosseous regional administration; $\mathrm{V} 110_{\mathrm{IV}}$ = systemic vancomycin, $110 \mathrm{mg} / \mathrm{kg} ; \mathrm{V} 25_{\mathrm{IV}}=$ systemic vancomycin, $25 \mathrm{mg} / \mathrm{kg} ; \mathrm{V} 25_{\text {IORA }}=$ IORA vancomycin, $25 \mathrm{mg} / \mathrm{kg} ; \mathrm{C} 100_{\text {IORA }}=$ IORA cefazolin, $100 \mathrm{mg} / \mathrm{kg} ; \mathrm{C} 100_{\mathrm{IV}}=$ systemic cefazolin, $100 \mathrm{mg} / \mathrm{kg}$. 
antibiotics must have adequate tissue concentrations at the operative site from the time of incision until the time of closure [5]. As antibiotic resistance increases, systemic administration of cephalosporins may no longer provide adequate tissue concentrations against coagulase-negative staphylococci and MRSA. IORA allows much higher tissue concentrations to be achieved [56, 57], and the current study showed that overall, IORA of cefazolin and vancomycin provided more effective prophylaxis than the same dose of antibiotic given systemically in a murine model of TKA.

There are a number of limitations to this study. First, although we attempted to use the equivalent antibiotic doses and copy the clinical situation of an intraarticular implant, it is unclear how well this model approximates the clinical situation of TKAs in humans. However because clinical TKA infection rates range between $0.86 \%$ and $2.5 \%$ [1, 3,
$37,41]$, animal models such as this remain the only practical way to provide adequate power to compare differing prophylaxis regimes. Second, we chose to investigate only MSSA, because vancomycin is likely to be more effective than cefazolin against coagulase-negative staphylococci and MRSA strains resistant to cefazolin. Similar to previous studies [38, 43], we used a relatively high inoculum of bacteria to better discriminate between the effectiveness of prophylactic regimes for the three endpoints used (in vivo bioluminescence, ex vivo implant, and periarticular tissue counts). This may differ from the clinical situation in TKA, because although contamination occurs in most if not all TKAs [12], the overall bacterial inoculum is likely to be lower than used in this model. In addition, vancomycin has a longer half-life than cefazolin which may have affected the comparison between groups as we used only one preoperative dose. However clinical data suggest the

Table 5. Staphylococcus aureus* recovered from periprosthetic tissue 4 days after surgery for effect of antibiotic treatment compared with no treatment

\begin{tabular}{lllr}
\hline Treatment & Median (range) & Difference of medians to control & $\mathrm{p}$ value \\
\hline Control & $1.17 \times 10^{8}\left(3.94 \times 10^{6}-5.37 \times 10^{8}\right)$ & \\
$\mathrm{V} 110_{\text {IV }}$ & $1.86 \times 10^{6}\left(9.59 \times 10^{3}-2.60 \times 10^{7}\right)$ & $1.15 \times 10^{8}$ & 0.1376 \\
$\mathrm{~V}^{2} 5_{\text {IV }}$ & $1.95 \times 10^{6}\left(6.64 \times 10^{2}-1.27 \times 10^{7}\right)$ & $1.15 \times 10^{8}$ & 0.0454 \\
V25 & $4.92 \times 10^{3}\left(1.16 \times 10^{2}-8.69 \times 10^{6}\right)$ & $1.17 \times 10^{8}$ & 0.0005 \\
C100 & $4.23 \times 10^{5}\left(<1.30 \times 10^{1}-9.69 \times 10^{6}\right)$ & $1.17 \times 10^{8}$ & 0.0049 \\
C100 & $7.67 \times 10^{6}\left(1.82 \times 10^{6}-1.63 \times 10^{8}\right)$ & $1.09 \times 10^{8}$ & 0.8699 \\
\hline
\end{tabular}

* Colony forming units; V = vancomycin; C = cefazolin; IV = intravenous; IORA - intraosseous regional administration.

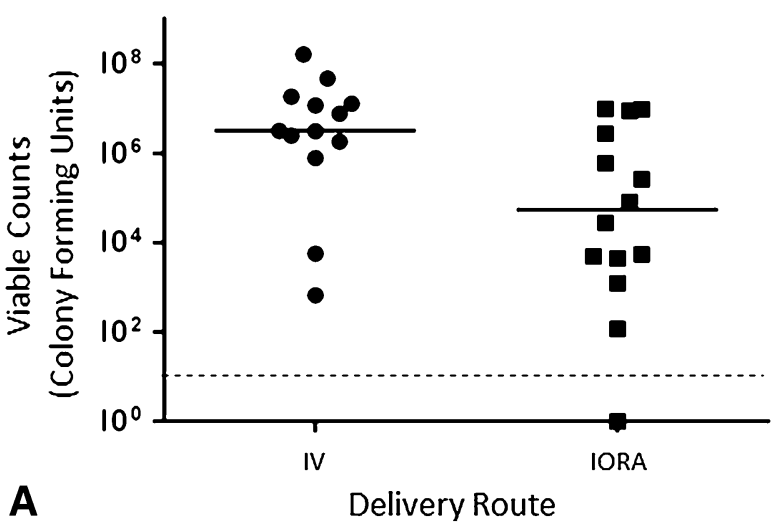

Fig. 6A-B The effect of the delivery route of prophylactic treatment on $S$ aureus Xen36 survival is shown. Mice treated with either $25 \mathrm{mg} /$ $\mathrm{kg}$ vancomycin or $100 \mathrm{mg} / \mathrm{kg}$ cefazolin were euthanized 96 hours after surgery for quantification of bacteria remaining in the (A) knee and surrounding tissue and (B) implanted K-wire. The dotted line

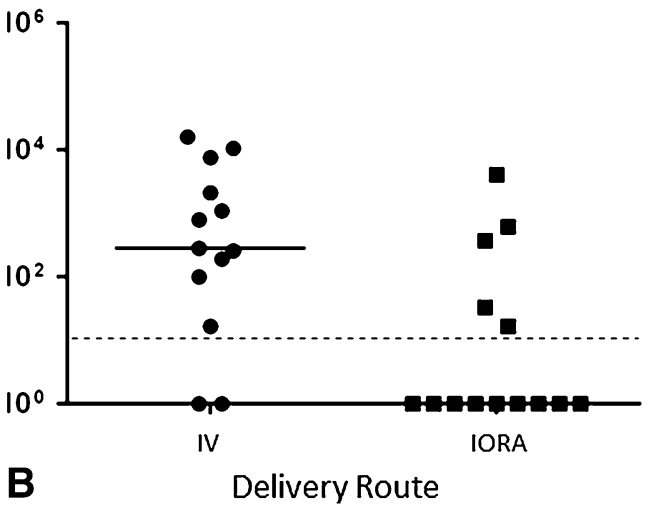

represents the limits of detection. Median values are denoted by solid lines. Each symbol represents an individual animal. Data are pooled from six independent repeats. IV = systemic administration; IORA = intraosseous regional administration. 
preoperative dose is the most important in providing prophylaxis $[15,16,21,51]$, and the faster rate of drug metabolism in the mouse means the effect of differing halflives is reduced [44]. Finally we used only female mice, as male mice are more likely to fight and injure themselves or other animals when group housed. In murine models female mice generally are more resistant to the development of bacterial infection [40], however previous studies using this TKA model also have been single-sex studies $[2,38]$ and male and female differences are not known.

We found in vivo bacterial burden 4 days after simulated TKAs to be lower than that of controls in both IORA groups (low-dose vancomycin and standard-dose cefazolin), and also in the group given high-dose systemic vancomycin. The rationale for using a low-dose of vancomycin with IORA relates to the multiple disadvantages of systemic vancomycin prophylaxis. Systemic vancomycin requires a prolonged administration time to prevent red man syndrome, a pruritic, erythematous rash related to histamine release with rapid infusion [32, 48]. A prophylactic dose of $1 \mathrm{~g}$ requires the infusion to be started a minimum of 1 hour before surgery, which is difficult to achieve in an arthroplasty practice [4]. Vancomycin also can cause renal and other systemic toxicity $[9,32]$. The use of a lower, targeted vancomycin dose through IORA optimizes timing of administration and reduces the risk of such systemic toxic effects.

Similar to data from biophotonic imaging, bacterial CFU counts from the implanted K-wire were lower than those of controls in both IORA groups, and in the group given high-dose systemic vancomycin. This suggests high tissue concentrations of vancomycin in particular are important in its efficacy as a prophylactic agent. The killing power of vancomycin is proportional to the area under the concentration versus time curve [45, 46]; thus, higher concentrations are likely to enhance efficacy, as seen in our study. Inadequate tissue concentrations have been implicated as the reason why systemic vancomycin is less effective than cephalosporins against MSSA [4, 42, 52]. Niska et al. [38] used a murine model of prophylaxis against implant infection to investigate the efficacy of varying doses of antibiotic. They found vancomycin to have a narrower effective dose range than daptomycin or tigecycline with a $110-\mathrm{mg} / \mathrm{kg}$ dose markedly more effective than a $10-\mathrm{mg} / \mathrm{kg}$ dose. Although estimation of equivalent human and mouse dosages is imperfect, our study supports the finding that the efficacy of vancomycin as a prophylactic agent depends on achieving high tissue concentrations. IORA vancomycin, which will achieve high concentrations despite the lower dose, resulted in lower bacterial counts and IORA vancomycin appeared at least as effective as cefazolin for prophylaxis against MSSA in our model. In clinical studies of prophylaxis in arthroplasty, vancomycin performs less well against MSSA than cephalosporins $[4,19]$. It seems likely that the clinical efficacy of vancomycin prophylaxis against MSSA will be enhanced if higher tissue concentrations can be achieved.

We found the same doses of vancomycin and cefazolin were more effective via IORA than an IV dose. Bactericidal activity of cefazolin normally is considered to be concentration-independent, and once tissue levels are four to five times the minimum inhibitory concentration, further increases do not increase efficacy [10]. Therefore while high tissue concentrations of cefazolin with IORA may provide benefit against organisms with high minimum inhibitory concentrations of cefazolin such as coagulasenegative staphylococci [55], they would be expected to have less effect on more-sensitive strains such as the MSSA used in our study. However, these data are based on animal models of treatment of established infections [31, 53], rather than models of prophylaxis such as ours in which prevention of infection is the goal. Initiation of bacterial killing is known to occur earlier with increasing cefazolin concentrations [10], a factor likely to be more important in prophylaxis where preventing initial bacterial adherence and subsequent biofilm formation is required. This may explain our finding of greater efficacy for IORA cefazolin prophylaxis compared with systemic administration of the same cefazolin dose.

IORA of prophylactic cefazolin and vancomycin was more effective than the same dose of antibiotic given systemically. The effectiveness of vancomycin in particular was enhanced by IORA administration despite a lower IORA dose, suggesting vancomycin is more effective against MSSA when high tissue concentrations such as with IORA are achieved. Further clinical studies are needed to identify any unforeseen complications with IORA use, particularly with vancomycin. The use of a lower dose and depot effect may reduce the risk of red man syndrome on tourniquet deflation, and this complication has not yet been seen in human studies of IORA vancomycin. Concerns regarding antibiotic stewardship remain, and routine use of vancomycin by any route may not be justified. IORA vancomycin may be more appropriately limited to patients at higher risk of infection, such as with revision procedures, and in patients with a high BMI [35]. Future clinical studies will focus on these areas.

Acknowledgments We thank Thomas Lumley PhD, Department of Statistics, University of Auckland, for helpful advice regarding statistical analysis.

Open Access This article is distributed under the terms of the Creative Commons Attribution 4.0 International License (http:// creativecommons.org/licenses/by/4.0/), which permits unrestricted use, distribution, and reproduction in any medium, provided you give appropriate credit to the original author(s) and the source, provide a link to the Creative Commons license, and indicate if changes were made. 


\section{References}

1. Bengtson S, Knutson K. The infected knee arthroplasty: a 6-year follow-up of 357 cases. Acta Orthop Scand. 1991;62:301-311.

2. Bernthal NM, Stavrakis AI, Billi F, Cho JS, Kremen TJ, Simon SI, Cheung AL, Finerman GA, Lieberman JR, Adams JS, Miller LS. A mouse model of post-arthroplasty Staphylococcus aureus joint infection to evaluate in vivo the efficacy of antimicrobial implant coatings. PLOS ONE. 2010;5:e12580.

3. Blom AW, Brown J, Taylor AH, Pattison G, Whitehouse S, Bannister GC. Infection after total knee arthroplasty. J Bone Joint Surg Br. 2004;86:688-691.

4. Bull AL, Worth LJ, Richards MJ. Impact of vancomycin surgical antibiotic prophylaxis on the development of methicillin-sensitive Staphylococcus aureus surgical site infections: report from Australian Surveillance Data (VICNISS). Ann Surg. 2012;256:10891092.

5. Burke JF. The effective period of preventive antibiotic action in experimental incisions and dermal lesions. Surgery. 1961;50: 161-168.

6. Caliper LifeSciences. Bioware ${ }^{\mathrm{TM}}$ Microorganism - Staphylococcus aureus Xen36 In vitro Characteristics. Available at: http:// www.perkinelmer.ca/FR-CA/CMSResources/Images/44-

136643DTS_Saureus_Xen_36-7506.pdf. Accessed June 16, 2015.

7. Carlsson AK, Lidgren L, Lindberg L. Prophylactic antibiotics against early and late deep infections after total hip replacements. Acta Orthop Scand. 1977;48:405-410.

8. Cavanaugh DL, Berry J, Yarboro SR, Dahners LE. Better prophylaxis against surgical site infection with local as well as systemic antibiotics: an in vivo study. J Bone Joint Surg Am. 2009;91:1907-1912.

9. Courtney PM, Melnic CM, Zimmer Z, Anari J, Lee GC. Addition of vancomycin to cefazolin prophylaxis is associated with acute kidney injury after primary joint arthroplasty. Clin Orthop Relat Res. 2015;473:2197-2203.

10. Craig WA. Pharmacokinetic/pharmacodynamic parameters: rationale for antibacterial dosing of mice and men. Clin Infect Dis. 1998;26:1-10; quiz 11-12.

11. Cunha BA, Gossling HR, Pasternak HS, Nightingale CH, Quintiliani R. The penetration characteristics of cefazolin, cephalothin, and cephradine into bone in patients undergoing total hip replacement. J Bone Joint Surg Am. 1977;59:856-859.

12. Davis N, Curry A, Gambhir AK, Panigrahi H, Walker CR, Wilkins EG, Worsley MA, Kay PR. Intraoperative bacterial contamination in operations for joint replacement. J Bone Joint Surg Br. 1999;81:886-889.

13. Doyon F, Evrard J, Mazas F, Hill C. Long-term results of prophylactic cefazolin versus placebo in total hip replacement. Lancet. 1987;1:860.

14. Fletcher N, Sofianos D, Berkes MB, Obremskey WT. Prevention of perioperative infection. J Bone Joint Surg Am. 2007;89: $1605-1618$.

15. Fonseca SN, Kunzle SR, Junqueira MJ, Nascimento RT, de Andrade JI, Levin AS. Implementing 1-dose antibiotic prophylaxis for prevention of surgical site infection. Arch Surg. 2006;141:1109-1113, discussion 1114.

16. Garcia S, Lozano ML, Gatell JM, Soriano E, Ramon R, Sanmiguel JG. Prophylaxis against infection: single-dose cefonicid compared with multiple-dose cefamandole. J Bone Joint Surg Am. 1991;73:1044-1048.

17. Garey KW, Dao T, Chen H, Amrutkar P, Kumar N, Reiter M, Gentry LO. Timing of vancomycin prophylaxis for cardiac surgery patients and the risk of surgical site infections. J Antimicrob Chemother. 2006;58:645-650.
18. Haley RW, Hightower AW, Khabbaz RF, Thornsberry C, Martone WJ, Allen JR, Hughes JM. The emergence of methicillinresistant Staphylococcus aureus infections in United States hospitals: possible role of the house staff-patient transfer circuit. Ann Intern Med. 1982;97:297-308.

19. Hawn MT, Richman JS, Vick CC, Deierhoi RJ, Graham LA, Henderson WG, Itani KM. Timing of surgical antibiotic prophylaxis and the risk of surgical site infection. JAMA Surg. 2013;148:649-657.

20. Healy DP, Polk RE, Garson ML, Rock DT, Comstock TJ. Comparison of steady-state pharmacokinetics of two dosage regimens of vancomycin in normal volunteers. Antimicrob Agents Chemother. 1987;31:393-397.

21. Heydemann JS, Nelson CL. Short-term preventive antibiotics. Clin Orthop Relat Res. 1986;205:184-187.

22. Hidayat LK, Hsu DI, Quist R, Shriner KA, Wong-Beringer A. High-dose vancomycin therapy for methicillin-resistant Staphylococcus aureus infections: efficacy and toxicity. Arch Intern Med. 2006;166:2138-2144.

23. Hill C, Flamant R, Mazas F, Evrard J. Prophylactic cefazolin versus placebo in total hip replacement: report of a multicentre double-blind randomised trial. Lancet. 1981;1:795-796.

24. Ichioka N, Inaba M, Kushida T, Esumi T, Takahara K, Inaba K, Ogawa R, Iida H, Ikehara S. Prevention of senile osteoporosis in SAMP6 mice by intrabone marrow injection of allogeneic bone marrow cells. Stem Cells. 2002;20:542-551.

25. Johnson DP. Antibiotic prophylaxis with cefuroxime in arthroplasty of the knee. J Bone Joint Surg Br. 1987;69:787-789.

26. Jonsson EÖ, Johannesdottir H, Robertsson O, Mogensen B. Bacterial contamination of the wound during primary total hip and knee replacement: median 13 years of follow-up of 90 replacements. Acta Orthop. 2014;85:159-164.

27. Kaplan AH, Gilligan PH, Facklam RR. Recovery of resistant enterococci during vancomycin prophylaxis. J Clin Microbiol. 1988;26:1216-1218.

28. Kunst MW, Mattie H, van Furth R. Antibacterial efficacy of cefazolin and cephradine in neutropenic mice. Infection. 1979;7:30-34.

29. Kushida T, Inaba M, Hisha H, Ichioka N, Esumi T, Ogawa R, Iida $\mathrm{H}$, Ikehara S. Intra-bone marrow injection of allogeneic bone marrow cells: a powerful new strategy for treatment of intractable autoimmune diseases in MRL/lpr mice. Blood. 2001;97: 3292-3299.

30. Lazzarini L, Novelli A, Marzano N, Timillero L, Fallani S, Viola $\mathrm{R}$, de Lalla F. Regional and systemic prophylaxis with teicoplanin in total knee arthroplasty: a tissue penetration study. $J$ Arthroplasty. 2003;18:342-346.

31. Leggett JE, Fantin B, Ebert S, Totsuka K, Vogelman B, Calame W, Mattie H, Craig WA. Comparative antibiotic dose-effect relations at several dosing intervals in murine pneumonitis and thigh-infection models. J Infect Dis. 1989;159:281-292.

32. McNamara DR, Steckelberg JM. Vancomycin. J Am Acad Orthop Surg. 2005;13:89-92.

33. Møller JK. Drug resistance and plasmid profiles in Staphylococcus epidermidis in 1964 and 1986. J Hosp Infect. 1988;12: 19-27.

34. Murphy E, Spencer SJ, Young D, Jones B, Blyth MJ. MRSA colonisation and subsequent risk of infection despite effective eradication in orthopaedic elective surgery. J Bone Joint Surg Br. 2011;93:548-551.

35. Namba RS, Inacio MC, Paxton EW. Risk factors associated with deep surgical site infections after primary total knee arthroplasty: an analysis of 56,216 knees. J Bone Joint Surg Am. 2013;95: $775-782$. 
36. New Zealand Animal Welfare Act 1999. Available at: http:// www.legislation.govt.nz/act/public/1999/0142/latest/DLM49664. html. Accessed June 16, 2015.

37. Nickinson RS, Board TN, Gambhir AK, Porter ML, Kay PR. The microbiology of the infected knee arthroplasty. Int Orthop. 2010;34:505-510.

38. Niska JA, Shahbazian JH, Ramos RI, Pribaz JR, Billi F, Francis $\mathrm{KP}$, Miller LS. Daptomycin and tigecycline have broader effective dose ranges than vancomycin as prophylaxis against a Staphylococcus aureus surgical implant infection in mice. Antimicrob Agents Chemother. 2012;56:2590-2597.

39. Norton TD, Skeete F, Dubrovskaya Y, Phillips MS, Bosco JD 3rd, Mehta SA. Orthopedic surgical site infections: analysis of causative bacteria and implications for antibiotic stewardship. Am J Orthop. 2014;43:E89-92.

40. Pasche B, Kalaydjiev S, Franz TJ, Kremmer E, Gailus-Durner V, Fuchs H, Hrabé de Angelis M, Lengeling A, Busch DH. Sexdependent susceptibility to Listeria monocytogenes infection is mediated by differential interleukin-10 production. Infect Immun. 2005;73:5952-5960.

41. Phillips JE, Crane TP, Noy M, Elliott TS, Grimer RJ. The incidence of deep prosthetic infections in a specialist orthopaedic hospital: a 15-year prospective survey. J Bone Joint Surg Br. 2006;88:943-948.

42. Ponce B, Raines BT, Reed RD, Vick C, Richman J, Hawn M. Surgical site infection after arthroplasty: comparative effectiveness of prophylactic antibiotics. Do surgical care improvement project guidelines need to be updated? J Bone Joint Surg Am. 2014;96:970-977.

43. Pribaz JR, Bernthal NM, Billi F, Cho JS, Ramos RI, Guo Y, Cheung AL, Francis KP, Miller LS. Mouse model of chronic post-arthroplasty infection: noninvasive in vivo bioluminescence imaging to monitor bacterial burden for long-term study. $J$ Orthop Res. 2012;30:335-340.

44. Reagan-Shaw S, Nihal M, Ahmad N. Dose translation from animal to human studies revisited. FASEB J. 2007;22:659-661.

45. Rybak MJ. The pharmacokinetic and pharmacodynamic properties of vancomycin. Clin Infect Dis. 2006;42(suppl 1):S35-39.

46. Rybak MJ, Lomaestro BM, Rotschafer JC, Moellering RC, Craig WA, Billeter M, Dalovisio JR, Levine DP. Vancomycin therapeutic guidelines: a summary of consensus recommendations from the Infectious Diseases Society of America, the American Society of Health-System Pharmacists, and the Society of Infectious Diseases Pharmacists. Clin Infect Dis. 2009;49: 325-327.
47. Shi M, Adachi Y, Cui Y, Li M, Lian Z, Zhang Y, Yanai S, Shima $\mathrm{C}$, Imai Y, Ikehara S. Combination of intra-bone marrow-bone marrow transplantation and subcutaneous donor splenocyte injection diminishes risk of graft-versus-host disease and enhances survival rate. Stem Cells Dev. 2011;20:759-768.

48. Sivagnanam S, Deleu D. Red man syndrome. Crit Care. 2003;7:119-120

49. Smith EB, Wynne R, Joshi A, Liu H, Good RP. Is it time to include vancomycin for routine perioperative antibiotic prophylaxis in total joint arthroplasty patients? J Arthroplasty. 2012;27(8 suppl):55-60.

50. Stefánsdóttir A, Johansson D, Knutson K, Lidgren L, Robertsson O. Microbiology of the infected knee arthroplasty: report from the Swedish Knee Arthroplasty Register on 426 surgically revised cases. Scand J Infect Dis. 2009;41:831-840.

51. Steinberg JP, Braun BI, Hellinger WC, Kusek L, Bozikis MR, Bush AJ, Dellinger EP, Burke JP, Simmons B, Kritchevsky SB; Trial to Reduce Antimicrobial Prophylaxis Errors (TRAPE) Study Group. Timing of antimicrobial prophylaxis and the risk of surgical site infections: results from the Trial to Reduce Antimicrobial Prophylaxis Errors. Ann Surg. 2009;250:10-16.

52. Tyllianakis ME, Karageorgos AC, Marangos MN, Saridis AG, Lambiris EE. Antibiotic prophylaxis in primary hip and knee arthroplasty: comparison between cefuroxime and two specific antistaphylococcal agents. J Arthroplasty. 2010;25:1078-1082.

53. Vogelman B, Gudmundsson S, Leggett J, Turnidge J, Ebert S, Craig WA. Correlation of antimicrobial pharmacokinetic parameters with therapeutic efficacy in an animal model. $J$ Infect Dis. 1988;158:831-847.

54. oodnutt G, Berry V, Mizen L. Simulation of human serum pharmacokinetics of cefazolin, piperacillin, and BRL 42715 in rats and efficacy against experimental intraperitoneal infections. Antimicrob Agents Chemother. 1992;36:1427-1431.

55. Yamada K, Matsumoto K, Tokimura F, Okazaki H, Tanaka S. Are bone and serum cefazolin concentrations adequate for antimicrobial prophylaxis? Clin Orthop Relat Res. 2011;469: 3486-3494.

56. Young SW, Zhang M, Freeman JT, Mutu-Grigg J, Pavlou P, Moore GA. The Mark Coventry Award: Higher tissue concentrations of vancomycin with low-dose intraosseous regional versus systemic prophylaxis in TKA: a randomized trial. Clin Orthop Relat Res. 2014;472:57-65.

57. Young SW, Zhang M, Freeman JT, Vince KG, Coleman B. Higher cefazolin concentrations with intraosseous regional prophylaxis in TKA. Clin Orthop Relat Res. 2013;471:244-249. 